\title{
Internet-Future Business Development Focus
}

\author{
Xiang Fang, Yangping Zhou \\ Tsinghua University, Beijing, China. \\ Email: fangxiang@tsinghua.org.cn, zhouyp@mail.tsinghua.edu.cn \\ Received October 23 ${ }^{\text {rd }}, 2011$; revised March 20 ${ }^{\text {th }}$,2012; accepted April 20 $0^{\text {th }}, 2012$
}

\begin{abstract}
The paper compares the characteristics of traditional business model to future business model development. Internet will be the most important growth point on business development. With the internet business growth and development or the potential customers growth, future business development and enlargement should be focused. The relevant contents discussion will be good to the future business development.
\end{abstract}

Keywords: Internet; Business Model; Business Development; Marketing

\section{Introduction}

Most businesses are focused on profit, revenue and customers. However, the affected factors to these business results including many things such as business leads, lead conversion rate, number of customer transaction, average selling price and reasonable margin etc. which are neglected very often. One of the fundamental challenges most businesses face is the generation of new leads. Without a constant supply of leads or without enough potential customers, they're faced with a never-ending battle to generate sufficient cashflow for the business to survive from one month to the next [1]. So internet is as one of most important marketing or business development tools to develop business and potential customers, it is should be focused on future business.

\section{Internet Rapid Growth to Marketing}

The key point of marketing to business development is making use of the speed of wideness of technique to access customers. From the brief review of marketing history, the rapid growth of internet to the importance of marketing can be found easily.

\subsection{Business Development Steps Relevant to Marketing}

The concept of marketing can be traced back to very old times. From then the road of marketing on business development can be clarified as below several steps.

1) Handicraft is the initial marketing

At very old times, people need to do buying and selling necessary goods in daily life. In order to clarify the difference, the workers created some signals to make the difference on their products. This is the initial marketing and brand. Obviously business development is not easy.

2) Printing machine lead to paper information

At the middle of $15^{\text {th }}$ century, printing machine appeared. Information can be spread through published papers. This is a very great development to marketing and business development. However, transportation speed limited the information spread.

3) Railway and telegraph

Although information can be printed, till roughly 150 years ago, buying and selling behavior only was below people walking or horse-riding limit. This decided the marketing spreading scope. With the railway and telegraph, business development and marketing faced a huge jump. Because people could easily buy and sell through the transportation tools development even if the distance is over $1000 \mathrm{~km}$. Telegraph could let marketing information arrive destination ahead of people. Business customers and potential leads increased very much. Thus business development is easier.

4) Telephone and automobile lead to mass marketing

Roughly one century ago, automobile appeared. With telephone technique break-though, a new marketing automobile combining with telephone happened. The method had been used today. Then besides newspaper and magazine, broadcast was as a new marketing and business development way happening. Thus more customers touching and the concept of mass marketing emerged.

5) Retail business marketing tools

With more and more make-up such as post, telephone, railway and automobile etc., retail business men used mail-order list way to promote products. It became one of most effective and legendary tools. After that with TV appeared, the golden time of marketing was coming. In 
the past half century, through TV, product list, voice based on wireless and creative advertisement combining together, more and more potential customers and business leads could be reached and got. So business development is blooming.

\subsection{Internet Bring More Opportunities and Play Important Part in Business Development}

The basic internet structure appeared on 40 years ago, it gave us a business platform. On this platform, we could play game, go shopping, watch TV, make friends and do research etc. With internet, we have to do many reforms [2].

In the past a few years, internet as a new media which reflected very quickly and penetrated strongly leaded to bombed growth on marketing directly. Almost everyone who has PC could set up web station and promote brand. The relevant investment is almost zero. The game rule had been totally changed [3].

Internet is becoming a marketing tool at our new time. It has brought us an unimaginable huge reform. In human history progressing, when the communication speed and wideness had tremendous and revolutionary progress, it would lead to a new height of marketing and business development. Internet time has surpassed any times of history. There is nothing like internet speed and wideness which could make us dizzy. And internet can be instant and global [4].

It is because internet almost could touch everyone and everywhere, our life and future will be affected greatly. Not only to our individual but also to our organization, environment, family etc. internet will bring us many things very much.

\section{Characteristics of Business Model Analysis}

Internet is growing rapidly. It is affecting our business model and changing the weight portion in our business. And the sustained impact trend will continue in the future.

\subsection{Traditional Business Model and Business Development}

Whether what kind of industries or business channels involved, the relevant business model from vendor to end user can be described briefly as Figure 1.

$\mathrm{B} 2 \mathrm{~B}$ business is relevant to direct sales and corporate reseller sales. B2C business is usually relevant to distributor sales. Internet business is very small especially 10 to 15 years ago. This business model had been lasted for many years. It is a traditional business model. For example in IT industry in China, B2B business is usually below $30 \%$. Internet business is usually below $5 \%$. The rest is the B2C business. Perhaps in other industries, the ratio is different. But the content is very similar. This is the characteristics of traditional business model and business development.

\subsection{Current and Future Business Model and Business Development}

In China, currently there are 457 million internet users, 303 million mobile internet users and 1.9 million domestic internet sites [5]. And the growth trend is very fast.

1) Internet business relevant to $B 2 C$

In 2010, top 5 China B2C internet vendors including Taobao, 360Buy, Joyo, Dangdang and Vancl retail online

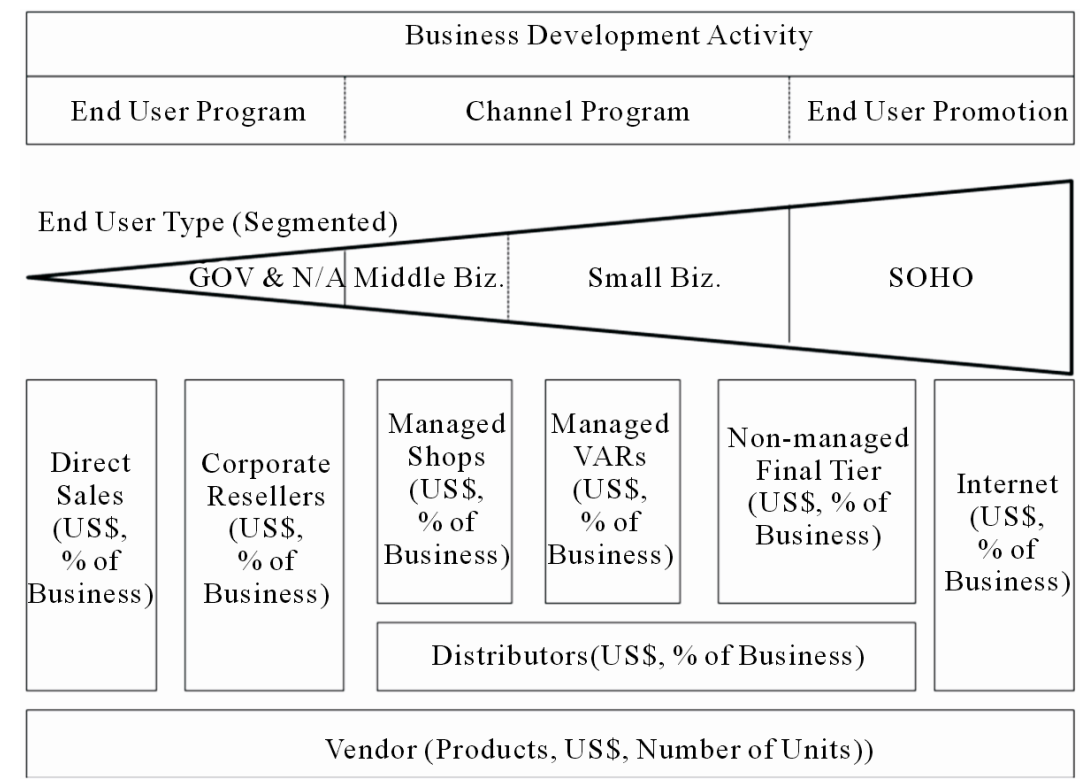

Figure 1. Traditional business model and business development. 
yearly revenue is nearly 50 billion RMB [6]. Though the revenue is not quite big, the potential rapid growth can be expected.

2) Internet business relevant to B2B and E business

According to the monitoring report of China $\mathrm{E}$ business, the yearly revenue in 2010 is 4500 billion RMB. The YOY growth is $22 \%$. B2B revenue is 3800 billion RMB. The YOY growth is $15.8 \%$. The internet retail total revenue is 513 billion RMB. There are roughly 25,000 E business vendors [7]. So the future business model and business development will be focused on internet.

\section{Future Business Development Management Platform}

From brief analysis above, internet as a business platform to business development will have bright potential in the future. So the relevant development direction and management points should be taken into consideration.

\subsection{Great Potential Internet Penetration in China}

Global internet penetration has been emphasized in many countries. The relevant data can be showed in Figure 2 [8].

Comparing to the developed countries, China has great potential on internet growth. In Germany and France, roughly $1 / 4$ business has used internet. In US, the data is $1 / 3$. However, in China, even 4500 billion RMB is relevant to internet business. The weight is only roughly $1 / 6$. So China has big room to improve internet business.

\subsection{Internet Has to Be the Focus of Business Development}

Internet will be business development focus based on its characteristics.

1) Business development focus

Reviewing most industries development, it is easily found that business development is usually from central cities to remote countryside. For example, in IT industry in China, businesses usually start from tier 1 city like
Beijing, Shanghai and Guangzhou. Then businesses develop to tier 2, tier 3 and so on. In the past a few years, business percentage outside tier 2 cities is growing very fast. Most vendors have paid more attention to below tier 3 cities business development.

2) Problem and solution

Although remote cities and countryside business grow rapidly, the percentage is usually below $30 \%$ in whole business in China. But this business weight is relevant to over 500 remote cities and over $90 \%$ Chinese population. It is easily found business cost be a big issue to any vendors in business development. So internet displays its advantage on this point. From wideness, speed, convenience and cost etc., internet has to be the best solution in business development. So it will have bright future.

\subsection{More Business Model Relevant to Business Development through Internet}

Besides B2B and B2C business model having been used in business development, some new business models are developing.

1) C2C business model

C2C means consumer to consumer. Internet can give buying and selling two sides an online platform. The trade can be processed conveniently.

2) B2M business model

$\mathrm{B} 2 \mathrm{M}$ means business to manager. It is a new business model. B2B, B2C and C2C business model treat customers object as consumers. But the customer object of B2M is enterprise or sales person relevant to products. For example, in China, the traditional internet user number is 140 million. However, to B2M business model, the number is 1400 million or whole Chinese. It is very different from other business model.

3) B2A business model

B2A means business to administrations or business between enterprise and government. In the future, the business model will be developed very quickly. Many government purchasing and IFB will use the business model.

4) C2A business model

C2A means consumer to administrations or business

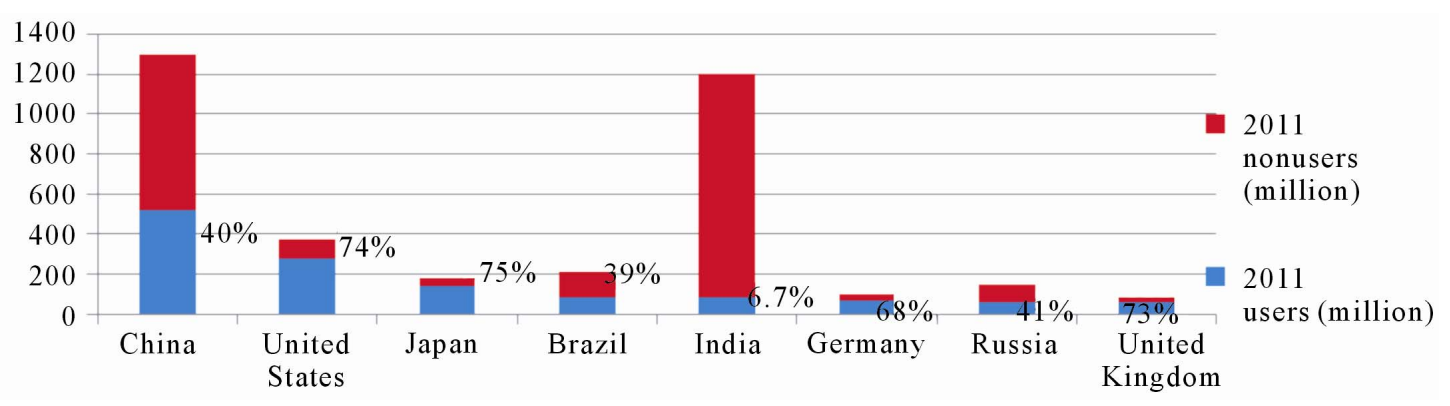

Figure 2. Global internet penetration. 
between individual and government. Currently the business model has not used. But in some developed country like Australia, individual uses internet to do taxation. It is the initial step to use the business model.

\subsection{More Things Need to Do Relevant to Business Development on Future Internet}

Internet is relevant to the several aspects including information service, trade and payment. The attendees on internet business include customer, vender, banking and authorization center. In the future, everything on business including customer lead, negotiation, order placing, online payment, invoice processing, custom, taxation and some logistics etc. will be realized through internet. The relevant sides need to change comparing to traditional business model.

1) Customer management

To the relationship marketing, we often call CRM or customer relationship management. In traditional business model, we can use 1 to 1 management method and try our best to meet customer need [9]. However, at internet time, how we can manage so huge number customers and differentiate their needs. It is really a problem we need to solve.

2) Business management

In traditional business model, we often use MBO or management by objective method. When setting up business objective, SMART method is often used. The objective is specific, measurable, achievable, relevant and time setting [10]. But from the characteristics of internet, business management whatever selling process, marketing, product, SCM and service etc. should be improved.

3) Taxation and other management

In order to manage internet business well, in China internet business shop registration begin to use real name and ID. Thus government and business administration can relevantly prepare to manage internet business easily in the future. For example, internet business taxation control and stock market taxation management etc.

\section{Summary}

In summary, internet brings the whole world more possibilities and opportunities. People in the world can communicate each other more rapidly and easily. With the growth of global internet user penetration, internet will play more important part in our daily life. Our new business model and business development will rely on the internet platform very much. More and more people can have relationship through internet platform. From business potential leads, customer getting, product demo, business negotiation, contract signing, order processing to payment, invoice opening, logistics, after sales service etc., internet supply everyone a big potential platform and opportunities. Future business development should focus on internet.

\section{REFERENCES}

[1] B. Sugars, "Instant Leads,” McGraw Hill Inc., New York, 2006.

[2] M. J. Cunningham, "E-Business,” Shanghai Far-East Press, Shanghai, 2002.

[3] J. Mariotti, "Brands and Branding," Shanghai Far-East Press, Shanghai, 2003.

[4] J. Mariotti, "Marketing," Shanghai Far-East Press, Shanghai, 2002.

[5] Information Volume 2, 2011. http://www.ceibs.edu/link

[6] Information on 2011. http://www.weste.net

[7] Information on Report of E Business Market Survey in 2010, 2011. http://www.sootoo.com

[8] Information on 2011. http://emarketer.com

[9] R. Jay, "Customers," Shanghai Far-East Press, Shanghai, 2003.

[10] G. L. Tang, C. Gao and C. Lu, "CEO Planning and Budget System,” Peking University Press, Beijing, 2010. 